\title{
Prosedur Keselamatan Dan Kesehatan Kerja (K3) Pada PT. Satunol Mikrosistem Jakarta
}

\author{
Herry Syafrial $^{\mathrm{a}, 1, *}$, Ahmad Ardiansyah ${ }^{\mathrm{b}, 2}$ \\ a Politeknik LP3I Jakarta, Administrasi Bisnis, Jalan Kramat Raya No. 7-9 Jakarta \\ b Politeknik LP3I Jakarta, Administrasi Bisnis, Jalan Kramat Raya No. 7-9 Jakarta \\ ${ }^{1}$ herrysyafrial@gmail.com *; ${ }^{2}$ ahmadardiansyah63@gmail.com \\ * corresponding author
}

ARTICLE INFO

\section{Article history}

Received

Revised

Accepted

Keywords

Procedure,

Safety,

Health

\begin{abstract}
The purpose of this writing is to find out how the K3 procedure in Jakarta's Satunol Mikrosistem and the obstacles faced in the K3 procedure and what solutions can be done to deal with these obstacles.

The research method that the author is doing is to look for references from books related to the title that the author took, then by interviewing methods, as well as direct observation to PT Satunol Microsystems.

The results of this study, the authors conclude that the K3 procedure at PT Satunol Mikrosistem has been running well and has been in accordance with the rules and provisions of the applicable laws in Indonesia.
\end{abstract}

\section{PENDAHULUAN}

Masalah Keselamatan dan Kesehatan Kerja (K3) secara umum di Indonesia masih sering terabaikan. Hal ini ditunjukkan dengan masih tingginya angka kecelakaan kerja. Berdasarkan data BPJS Ketenagakerjaan, terdapat 123.000 kasus kecelakaan kerja di tahun 2017 dan 157.313 kasus kecelakaan kerja di sepanjang 2018. Angka tersebut berasal dari beberapa kategori. Angka tersebut menunjukkan tingkat kecelakaan kerja di Indonesia naik setiap tahunnya. Sementara itu, data Badan Pusat Statistik (BPS) pada Agustus 2018, sebanyak 58,76 persen dari total angkatan kerja Indonesia adalah tamatan SMP ke bawah. Hal tersebut berdampak pada kesadaran pentingnya perilaku selamat dalam bekerja.

Rendahnya perhatian perusahaan terhadap keselamatan dan kesehatan kerja menyebabkan tingginya angka kematian dan kecelakaan kerja. Pelaksanaan K3 yang buruk di tempat kerja merupakan suatu proses yang dapat menimbulkan kecelakaan, dimana akibat yang ditimbulkan tidak hanya berdampak negatif terhadap tenaga kerja, akan tetapi dapat juga mempengaruhi penilaian masyarakat atau pengguna jasa perusahaan tersebut.

Dengan pelaksanaan K3 yang baik dapat meningkatkan keselamatan dan kesehatan pekerja, dan meningkatkan produktivitas kerja. Sehingga menjadikan K3 bukan hanya sebagai kewajiban perusahaan, tetapi menjadi kebutuhan pekerja dan perusahaan untuk melindungi tenaga kerjanya. Karena itu disamping perhatian perusahaan, pemerintah juga perlu memfasilitasi dengan peraturan atau aturan perlindungan Keselamatan dan Kesehatan Kerja.

PT. Satunol Mikrosistem merupakan perusahaan yang bergerak di bidang desain dan manufaktur produk elektronik yang bekerja berdasarkan kebutuhan pelanggan. PT. Satunol Mikrosistem merancang dan membangun sebuah produk elektronik yang dapat melakukan monitoring dan pengaturan jarak jauh. Sensor yang dikembangkan merupakan teknologi terbaru sehingga dapat menyediakan data yang aman untuk pengawasan secara terus menerus. Tentunya dalam prosedur K3 terdapat beberapa masalah dalam fasilitas keselamatan dan kesehatan kerja.

Harapan kedepannya PT Satunol Mikrosistem dapat terus memperhatikan prosedur K3 dalam kegiatan perusahaannya dengan baik, agar memberikan rasa nyaman bagi setiap tenaga kerjanya yang bekerja dengan resiko yang tinggi, dan mengikuti aturan dan ketentuan undang-undang yang berlaku. 
Berdasarkan uraian-uraian tersebut, penulis menjadikan perusahaan PT Satunol Mikrosistem sebagai salah satu objek untuk melakukan observasi serta mengurainya dalam bentuk tulisan dengan judul yaitu: "Prosedur K3 Pada PT Satunol Mikrosistem Jakarta".

\section{TINJAUAN PUSTAKA}

\section{Pengertian Keselamatan dan Kesehatan Kerja}

Menurut Suwardi dan Daryanto (2018:3) definisi keselamatan dan kesehatan kerja adalah: Bidang yang terkait dengan kesehatan, dan kesejahteraan manusia yang bekerja di sebuah institusi maupun lokal proyek.

Menurut Husni (2003) dalam Sopiah dan Etta Mamang Sangadji (2018:327) definisi keselamatan dan kesehatan kerja adalah: Ilmu pengetahuan dan penerapannya dalam usaha mencegah kemungkinan terjadinya kecelakaan dan penyakit akibat kerja ditempat kerja.

Menurut Suwardi dan Daryanto (2018:4) definisi keselamatan dan kesehatan kerja adalah: Instrumen yang memproteksi pekerja, perusahaan, lingkungan hidup, dan masyarakat sekitar dari bahaya akibat kecelakaan kerja.

Menurut Lijan Poltak Sinambela (2018:360) definisi K3 adalah: variabel yang dapat memberikan ketenangan dalam melaksanakan pekerjaannya.

Menurut Arif Yusuf Hamali (2018:164) definisi K3 adalah: menunjukkan kondisi yang aman atau selamat dari penderitaan, kerusakan atau kerugian ditempat kerja.

Dan beberapa ahli lain yang mendefinisikan K3 seperti Mangkunegara, Malinasari dan Azzuhri dan Putri dengan redaksi yang hampir sama.

\section{Tujuan dan Manfaat K3}

Adapun menurut Irzal (2016:19) menjelaskan tujuan K3 adalah untuk mencegah terjadinya kecelakaan kerja, penyakit, kematian, dan cacat tetap. Memelihara bangunan, material, alat dan mesin kerja. Meningkatkan produktivitas, produksi, kebersihan tempat kerja, dan menghindari inefisiensi.

Menurut Mangkunegara (2002:165) dalam Qomariyatus Sholihah dan Rahmi Fauzia (2015:22) bahwa tujuan dari K3 adalah agar setiap pegawai mendapatkan jaminan keselamatan, kesehatan, lingkungan kerja yang kondusif, keamanan, dan proteksi.

\section{Ruang Lingkup K3}

Menurut Rachman (1990) dalam Suwardi dan Daryanto (2018:4) ruang lingkup K3 meliputi semua aspek manusia sebagai tenaga kerja yang dilaksanakan secara menyeluruh dari mulai perencanaan hingga produksi barang atau jasa dan melibatkan semua level manajemen untuk menyukseskan keberhasilan K3.

\section{Landasan Hukum K3}

Syafi'i (2008:46) dalam Qomariyatus Sholihah dan Rahmi Fauzia (2015:23) memaparkan landasan hukum K3 sebagai berikut: KepMen Kesehatan RI No.1405/MENKES/SK/XI/2002 tentang persyaratan kesehatan lingkungan kerja perkantoran dan industri; Sistem manajeman K3 dalam Peraturan Menteri Tenaga Kerja RI No. Per-05/MEN/1996; Surat Keputusan Bersama Menteri Tenaga Kerja dan Menteri Kesehatan RI No.235/MEN/1985, No.114/MENKES/SKB/85 tentang Penyelenggaraan Pemeliharaan Kesehatan bagi Tenaga Kerja; ruang lingkup, syarat, pengawasan, pembinaan, kecelakaan, hak dan kewajiban tenaga kerja, memasuki tempat kerja, kewajiban pengurus, dan ancaman pidana bagi pelanggar dalam UU No 1 tahun 1970; rativikasi ILO No. 811947 dalam UU No. 21 tahun 2003; UU No. 13 tahun 2003 tentang Ketenagakerjaan; dan UU No.36 tahun 2009 tentang kesehatan.

\section{Syarat Keselamatan dan Kesehatan Kerja}

Menurut Qomariyatus Sholihah dan Rahmi Fauzia (2015:19) Berdasarkan UU No. 1 Tahun 1970 mengenai keselamatan kerja alinea ke III, syarat-syarat K3 meliputi pencegahan kecelakaan, kebakaran, ledakan, pengendalian suhu, kelembaban, debu, kotoran, sinar radiasi, suara, dan getaran, penyakit dan penularannya, bahaya aliran listrik. Penyelamatan jika terjadi kebakaran dan bencana alam, kecelakaan, alatalat proteksi bagi pekerja. Pengamanan angkutan barang, bangunan tempat kerja, proses bongkar muat.

Herry Syafrial, et.al (Prosedur Keselamatan Dan Kesehatan Kerja (K3) Pada PT. Satunol ...) 
Penyelenggaraan penerangan cahaya yang memadai, suhu dan kelembaban udara yang baik, udara yang segar dan bersih, untuk mendapatkan keharmonisan pekerja, alat kerja, dan lingkungan.

\section{Prosedur Keselamatan dan Kesehatan Kerja}

\section{Pengertian Prosedur Keselamatan dan Kesehatan Kerja}

Menurut Suryati Darmiatun dan Tasrial (2015:18) definisi prosedur K3 adalah meliputi pencegahan deviasi-deviasi dari kegiatan dan tujuan K3 yang telah ditetapkan sebelumnya.

Menurut Suryati Darmiatun dan Tasrial (2015:18) ada hal-hal yang harus diperhatikan dalam pembuatan prosedur K3 dalam organisasi:

a. Komitmen organisasi dalam penerapan manajemen K3

b. Fokus/jenis, kompleksitas struktur dan ukuran organisasi

c. Sifat dan skala risiko-risiko organisasi.

d. Keterlaksanaan prosedur (mudah dioperasikan oleh user); dan

e. Keterukuran dan mampu evaluasi dari hasil pelaksanaan prosedur.

\section{Prosedur Keselamatan dan Kesehatan Kerja}

Menurut OHSAS 18001;2007 dalam Suryati Darmiatun dan Tasrial (2015:19) ada beberapa tahap atau prosedur dalam keselamatan dan kesehatan kerja:

\section{Identifikasi potensi bahaya dan melakukan penilaian dan pengendalian resiko}

Mengidentifikasi bahaya yang terjadi sebelum bekerja seperti mengecek kondisi pelaksana pekerjaan (manusia), peralatan yang digunakan, standar kerja, lingkungan tempat kerja baik fisik maupun non fisik, energi yang terlibat seperti, listrik, panas, kimia, radiasi, dan lain-lain dan identifikasi aspek dampak lingkungan operasional organisasi terhadap alam dan penduduk di sekitarnya.

Penilaian resiko adalah melakukan proses evaluasi atas risiko-risiko yang diakibatkan adanya bahayabahaya, dengan memperhatikan kecukupan pengendalian yang dimiliki, dan menentukan apakah resikonya dapat diterima atau tidak.

Identifikasi potensi bahaya dan menilai resiko dilakukan dengan mengevaluasi semua kegiatan pegawai, potensi bahaya terhadap K3, Prasarana dan alat kerja yang dipergunakan, lingkungan, peraturan yang berlaku, dan rancangan instalasi, mesin, dan SOP yang disesuaikan dengan kesiapan dan K3 pekerja.

\section{Identifikasi peraturan K3 dan evaluasi pemenuhannya}

Perusahaan wajib menjalankan peraturan dan undang-undang dalam implementasi K3, tujuannya agar dapat mengevaluasi peraturan yang berlaku untuk mengetahui kelebihan dan kekurangan nya sehingga dapat memberikan masukan untuk penyempurnaan.

\section{Kompetensi, pelatihan, dan kepedulian}

Memberikan pelatihan kepada pekerja hingga kompetensi dan mendapat sertifikat K3, hal ini dilakukan untuk meningkatkan pengetahuan pekerja serta memberikan label bahwa pekerja tersebut sudah mendapat lisensi mengenai keselamatan dan kesehatan kerja.

\section{Komunikasi, partispasi, dan konsultasi}

Setelah diidentifikasi dan dievaluasi, perusahaan juga diharapkan dapat menyampaikan hasilnya ke dalan dan luar perusahaan. Hasil evaluasi disampaikan ke pihak terkait sebagai bahan masukan dan penyempurnaan perundang-undangan yang sudah ada.

\section{Pengendalian dokumen}

Dokumen yang berupa kertas, file, foto dari bukti-bukti kegiatan dan hasil yang telah dicapai. Semua dokumen ini dipelihara untuk memastikan ketersediaan, terbaca dengan jelas, memilah dokumen yang sudah kadaluarsa, dan menjaga dokumen penting dari pihak eksternal.

\section{Kesiapsiagaan dan tanggap darurat}

Perusahaan harus membuat aturan yang jelas untuk penyelamatan dalam keadaan darurat. Perusahaan juga menyiapkan sarana keselamatan dan pelatihan-pelatihan tanggap darurat untuk semua pekerja. 


\section{Pemantauan dan Pengukuran Kinerja}

Dalam hal ini mencakup inspeksi, pemantauan kesehatan, dan pemantauan lingkungan kerja, sasaran dan program, Frekuensi rate (FR) severity rate, health rate, dan kalibrasi.

\section{Evaluasi kesesuaian}

Semua dokumen evaluasi pelaksanaan K3 disimpan secara periodik dan dapat digabungkan dengan evaluasi kesesuaian dengan peraturan dan perundangan yang berlaku.

\section{Investigasi kecelakaan kerja}

Perusahaan harus menyeidiki kecelakaan kerja yang terjadi. Hal ini dianalisa dan dicatat untuk mengetahui penyebab, tindakan perbaikan, dan menyampaikan hasil penyelidikan.

\section{Penanganan ketidaksesuaian, tindakan perbaikan dan pencegahan}

Temuan ketidaksesuaian harus ditanggapi dengan cepat unutk proses perbaikan sehingga hal yang sama tidak terjadi lagi di kemudian hari.

\section{Audit Internal}

Perusahaan juga harus membentuk Sistem Pengendalian Internal (SPI) untuk mengaudit secara berkala terhadap pelaksanaan K3 di perusahaan. Hasil temuannya diberikan kepada manajemen sebagai bahan perbaikan.

\section{METODE PENELITIAN}

Dalam menyelesaikan penulisan ini teknis pelaksanaannya dan prosedur yang penulis gunakan mendapatkan data guna penyusunan laporan meliputi beberapa metode penelitian, metode ini terdiri dari:

\section{Studi Kepustakaan}

Yaitu pengumpulan data-data yang dilakukan dengan cara mempelajari berbagai macam bahan tertulis seperti buku-buku penunjang kajian, catatan-catatan, maupun referensi lain yang bersifat tertulis.

\section{Wawancara dan Pengamatan langsung}

\section{HASIL DAN PEMBAHASAN}

\section{Prosedur Keselamatan dan Kesehatan Kerja pada PT Satunol Mikrosistem}

Prosedur K3 pada PT Satunol Mikrosistem ada beberapa tahap, setiap tahap yang dibuat bertujuan untuk menjamin kelangsungan pekerjaan secara berkesinambungan melalui upaya pencegahan kecelakaan kerja. Berikut penjelasan alur Prosedur Kesehatan dan Keselamatan Kerja Pada PT Satunol Mikrosistem:

\section{Sosialisasi Mengenai K3}

Guna meningkatkan mutu keselamatan dan kesehatan kerja maka dari itu PT Satunol Mikrosistem memberikan sosialisasi mengenai K3 setiap harinya kepada karyawan, terutama kepada team yang bekerja dilapangan. Sosialisasi ini dilakukan oleh Project Manager atas perintah Managing Direktur, yang dilakukan di PT Satunol Mikrosistem yaitu dengan Project Manager mengumpulkan semua karyawan dalam satu ruangan khusus seperti layaknya briefing sebelum kerja, yang nantinya akan diberikan arahan mengenai standar kerja dan pentingnya keselamatan kerja.

Project Manager melakukan berbagai macam pendekatan salah satunya dengan pendekatan kekeluargaan yaitu dengan memberikan Statement kepada pekerja yaitu "Bekerja dengan selamat bahwa keluarga tercinta menunggu dirumah". Dengan kata-kata tersebut maka pekerja akan selalu teringat tentang keluarga serta menambah motivasi bekerja secara tidak langsung.

a. Ada beberapa cara sosialisasi kepada karyawan yaitu melalui :

\section{Safety Induction}

Safety Induction sangat penting bagi pekerja baru, pindahan, mutasi, kontraktor dan tamu yang berada di tempat kerja. Maka dari itu setiap pekerja baru ataupun tamu perusahaan yang datang ke 
lokasi kerja, OHS Officer wajib memberikan arahan aturan dan APD yang harus digunakan sebelum memasuki suatu tempat kerja yang memiliki resiko tinggi. Agar memberikan rasa aman kepada pekerja maupun tamu perusahaan.

\section{Safety Spesific}

Yaitu berkaitan dengan pemberian tugas kerja. Seorang Project Manager wajib memberikan tugas kerja sesuai dengan keahliannya dan pedoman K3 dari klien serta seorang OHS Officer wajib memberi contoh cara pemakaian alat pelindung diri dengan benar. Klien juga menyediakan buku panduan mengenai K3 yang nantinya juga akan dibahas dalam sosialisasi.

\section{Safety Morning}

Yaitu berkaitan dengan kebersamaan pekerja. Safety morning adalah bagian dari kesehatan dimana seorang PM mengajak seluruh pekerja lapangan untuk selalu menjaga kesehatannya yaitu dengan berolahraga bersama setiap sepekan sekali di perusahaan. Selain untuk menjaga kesehatan sosialisasi ini dapat mempererat kekeluargaan yang terjalin sesama pekerja.

b. Sosialisasi ini dilakukan dengan tujuan :

1. Agar pekerja lebih berhati-hati dalam bekerja dan dapat saling mengingatkan rekan-rekan kerjanya jika ada tindakan atau kondisi yang tidak aman.

2. Meminimalisir terjadinya kecelakaan kerja dan agar pekerja selalu teringat pentingnya keselamatan kerja.

3. Memberikan wawasan kepada setiap pekerja tentang K3 agar para pekerja merasa aman.

4. Menjadi salah satu komitmen PT Satunol Mikrosistem dalam mengedepankan mutu K3.

\section{Mengikuti Pelatihan/Sertifikasi Keselamatan dan Kesehatan Kerja}

PT Satunol Mikrosistem setiap tahunnya selalu memberikan pelatihan dan sertifikasi kepada pekerja lapangan. Pelatihan/Sertifikasi K3 dilaksanakan oleh Allsys \& Waterland dimana mereka sudah mendapatkan lisensi dari Depnaker.

Perusahaan sebelumnya sudah mengadakan rapat internal kepada pihak manajemen mengenai membiayai sertifikasi kepada para pekerja. Dikarenakan tidaklah murah dalam membiayai pekerja mengikuti sertifikasi K3. Maka dari itu perusahaan harus memilih kandidat yang tepat untuk pelatihan ini diberikan. Setelah adanya kesepakatan untuk berapa orang yang akan mengikuti pelatihan/sertifikasi, Project Manager akan menunjuk sebagian orang untuk mengikuti sertifikasi tersebut. Dan yang wajib mengikuti program ini adalah pekerja baru.

a. Dalam menunjuk beberapa kandidat terbaik yang akan mengikuti sertifikasi tersebut PM akan memeriksa beberapa persyaratan sebagai berikut:

1) Kesehatan (jasmani/rohani) kandidat

2) Tamatan sekolah kandidat

3) Cara kerja kandidat

4) Kedisiplinan kandidat

5) Attitude kandidat

6) Pengetahuan kandidat

Setelah terpilih beberapa kandidat yang akan diberikan pelatihan, PM membuat laporan pelatihan K3 agar segera di proses di bagian divisi keuangan. Setelah divisi keuangan menyatakan untuk dijalankan. PM segera memanggil kandidat yang sudah terpilih untuk diberikan pengarahan sebelum melakukan kegiatan pelatihan/sertifikasi.

Dengan adanya pelatihan/ sertifikasi ini dimaksudkan untuk meningkatkan knowladge, skill, attitude, dan dapat memberikan contoh rekan kerjanya mengenai keselamatan kerja, sehingga harus dirancang sesuai atau spesifik dengan kebutuhan masing-masing pekerja.

Project Manager bertanggung jawab untuk memastikan bahwa semua pekerja mereka telah cukup mengikuti pelatihan-pelatihan sesuai dengan pekerjaan yang akan dilakukan. 
b. Pekerja lapangan terutama yang bekerja di site BTS milik klien juga wajib bertanggung jawab untuk melakukan hal-hal sebagai berikut:

1) Pelatihan orientasi keselamatan dan kesehatan kerja

2) Pelatihan mengenai perundang-undangan keselamatan dan kesehatan kerja.

3) Rapat -rapat keselamatan dan kesehatan kerja.

4) Pelatihan keselamatan dan kesehatan kerja bagi para supervisior.

5) Pelatihan identifikasi bahaya.

6) Pelatihan memanjat tower dengan aman (Safety Tower Climbing)

7) Safety Talks / Tool Box Meeting.

c. Alasan perusahaan memberikan pelatihan K3 kepada karyawan dengan tujuan:

1) Untuk memberikan pengetahuan, dan keterampilan $K 3$.

2) Memiliki payung hukum yang kuat dalam pekerjaan yang memiliki resiko kecelakaan tinggi.

3) Mendapatkan informasi terbaru tentang K3.

4) Meningkatkan produktivitas dan mengurangi kecelakaan kerja.

5) Mengetahui prosedur kesiapsiagaan terhadap kondisi darurat dan bencana.

\section{Mengecek dokumen pelatihan/sertifikasi K3 pekerja}

Sebelum pekerja melakukan tugasnya seorang OHS Officer harus memastikan bahwa karyawan yang akan bertugas sebelumnya sudah mengikuti pelatihan/sertifikasi atau belum. Yaitu dengan mengecek kelengkapan dokumen sertifikasi setiap orangnya. Dokumen sertifikasi wajib di simpan dan dijaga oleh $O H S$ Officer. Setelah OHS Officer menyatakan pekerja memenuhi syarat selanjutnya pekerja mengisi form surat izin kerja. Bagi pekerja baru atau yang belum memiliki sertifikasi K3 pekerja tidak boleh melakukan pekerjaan yang beresiko tinggi. Pekerja baru wajib ditraining terlebih dahulu dengan pengawasan dari Engineering Leader Team. Setelah ditraining pekerja baru menunggu giliran untuk mengikuti sertifikasi dari perusahaan.

\section{Melengkapi surat izin kerja untuk pekerjaan yang beresiko tinggi}

Surat izin kerja diterbitkan oleh OHS Officer yang selanjutnya akan diisi oleh para pekerja. Sebelumnya pekerja tersebut melakukan cek kesehatan terlebih dahulu. Surat izin kerja dikeluarkan oleh OHS Officer setelah mendapat persetujuan dari Managing Director.

\section{Melakukan pengecekan kelayakan APD}

OHS Officer wajib melakukan safety control setiap hari berupa mengecek kelayakan dan kelengkapan alat-alat pelindung diri yang akan di gunakan pekerja. Setelah dinyatakan APD layak pakai dan sudah mendapatkan approve dari OHS manager selanjutnya APD di masukkan kedalam mobil dan pekerja melanjutkan jalan ke lokasi site yang sudah ditentukan.

Bila ditemukan APD yang tidak layak pakai untuk bekerja, maka APD tersebut tidak boleh untuk digunakan. OHS Officer segera membuat laporan untuk segera menggantikan APD yang layak pakai.

Safety control dilakukan untuk meminimalisir ataupun mencegah terjadinya kecelakaan kerja saat bekerja, dan memberikan rasa nyaman kepada para pekerja yang bekerja dengan tingkat resiko yang tinggi.

\section{Pekerja Wajib Menggunakan Alat Pelindung Diri}

Alat Pelindung Diri adalah kelengkapan yang wajib digunakan pekerja/team sesuai bahaya dan risiko kerja untuk menjaga keselamatan pekerja itu sendiri dan orang di sekelilingnya. Perusahaan wajib memfasilitasi APD untuk karyawannya yang bekerja dengan resiko yang tinggi. Kewajiban itu sudah disepakati oleh pemerintah melalui Departemen Tenaga Kerja Republik Indonesia. Adapun bentuk dari alat tersebut adalah:

\section{a. Pelindung Kepala (Helmet)}

Dilarang menggunakan helmet dari metal dan bump cap saat kerja di site. Helmet harus senantiasa dipakai selama berada di site, kecuali jika sedang istirahat diluar atau makan diluar site dan jika sedang berada di dalam ruangan yang tertutup (beratap). Helmet tidak boleh diberi tambahan aksesors atau dimodifikasi. Helmet harus memenuhi standar SNI (Standar Nasional Indonesia). 


\section{b. Full Body Harness}

Berupa rangkaian tali yang menopang tubuh untuk melakukan pekerjaan di ketinggian.

\section{c. Pelindung Penglihatan}

Alat pelindung penglihatan harus dipakai sesuai dengan jenis pekerjaan yang sedang dilakukan. Alat harus memenuhi standar SNI. Kacamata safety harus dilengkapi pelindung samping pada saat melakukan pekerjaan penggerindaan, maka wajib memakai alat pelindung muka (face shield). Pekerjaan yang memakai kacamata jarak jauh /pendek tetap wajib memakai kacamata safety yang sesuai untuk itu (Over-The-Glass safety Glassess).

\section{d. Pelindung Pernafasan}

Jika manajemen atau pihak lain yang terkait melihat bahwa pekerjanya perlu memakai alat pelindung pernafasan, maka mereka wajib memilih alat pelindung pernafasan yang sesuai, seperti misalnya debu udara. Alat pelindung pernafasan harus dipilih sesuai dengan bahaya yang ada yang dapat mempengaruhi pekerja. Alat pelindung pernafasan harus memenuhi standar SNI. Alat pelindung pernafasan harus disimpan dan dirawat sesuai dengan petunjuk dari pabrik pembuat.

\section{e. Pelindung Pendengaran}

Jika kondisi di site memungkinkan adanya suara/bising yang melebihi nilai ambang batas standar (80db), maka managmen perusahaan atau pihak lain yang terkait wajib menyediakan alat pelindung pendengaran bagi pekerja. Alat pelindung pendengaran harus memenuhi standar SNI. Manajemen atau pihak lain yang terkait wajib menyediakan tanda peringatan yang menunjukan bahwa pada satu area tertentu diwajibkan memakai alat peindung pendengaran.

\section{f. Pelindung Kaki}

Sepatu safety wajib di pakai selama berada di site. Sepatu safety harus memenuhi standar SNI. Khusus untuk pekerjaan sipil (civil) seperti misalnya penggalian, pengecoran, pemasangan batu bata/tembok/dinding dan sejenisnya maka diperbolehkan memakai sepatu karet (rubber boot). Sepanjang pekerjaan tersebut tidak ada kemungkinan si pekerja tertimpa besi pada kakinya.

\section{g. Pelindung Tangan}

Pekerja yang bekerja di site/menara telekomunikasi wajib memakai sarung tangan kerja sesuai dengan jenis pekerjaan yang dilakukan. Sarung tangan kulit atau katun harus dipakai jika pekerjaan yang dilakukan dapat mengakibatkan tangan terluka/tergores, seperti pada pekerjaan sipil dan sebagainya. Pekerja harus memakai sarung tangan karet (anti listrik) jika sedang bekerja di peralatan yang mengandung listrik. Sarung tangan tidak diperlukan (boleh tidak dipakai) jika pekerjaan yang dilakukan bersifat sangat cermat (detail) yang memerlukan keterampilan jari. Sarung tangan harus dalam kondisi baik. Tidak berlubang atau sobek dan harus memenuhi standar SNI.

\section{h. Pakaian Kerja}

Semua pekerja wajib memakai pakaian kerja yang baik, bersih, dan sopan saat melaksankan peerjaannya. Dilarang memakai celana pendek saat sedang berada di site. Pakaian yang tekena minyak, gemuk, oli atau bahan yang mudah terbakar dilarang dipakai. Apabila bekerja di dekat mesin/alat yang berputar, maka pakaian kerja tidak boleh terurai atau ada bagian yang terlepas, guna mencegah agar tidak terjerat oleh alat/mesin yang berputar tersebut.

\section{Dokumentasi}

Dokumentasi sangat penting untuk memastikan konsistensi dari penerapan K3. Dimana Engineering Leader diberikan tanggung jawab untuk memellihara dokumentasi yang ada berupa foto, video, dokumen perintah kerja serta data rekaman yang berhubungan dengan identifikasi bahaya, penilaian dan pegendalian resiko. Dokumentasi akan diberikan oleh OHS Officer agar dijadikan sebagai laporan harian bahwa telah melakukan sebuah pekerjaan dan penerapan K3. 


\section{Melakukan penanganan keadaan darurat}

Tanggap darurat merupakan elemen penting dalam prosedur K3, untuk menghadapi setiap kemungkinan yang dapat terjadi. Tanggap darurat sering diabaikan karena penuh ketidakpastian. Kita tidak tahu kapan gempa bumi, badai, petir, atau ledakan akan terjadi.

\section{Melakukan penanganan kecelakaan kerja}

Dalam hal ini jika terjadi kecelakaan kerja, maka penanganan kecelakaan kerja yang pertama dilakukan dengan pertolongan pertama oleh rekan kerja kepada pekerja yang mengalami kecelakaan. Jika memang kecelakaan tersebut dinyatakan serius dan butuh tim medis maka perusahaan segera menghubungi rumah sakit terdekat lokasi kecelakaan kerja untuk mengirimkan ambulance.

Di PT Satunol Mikrosistem sendiri sudah memiliki jaminan kesehatan bagi setiap karyawannya yaitu menggunakan BPJS Ketenagakerjaan dan BNI Life. Setiap kecelakaan yang terjadi Engineering Leader wajib memberitahukan kepada Coordinator Safety yang nantinya akan disampaikan kepada Project Manager.

Bila sakitnya akibat kecelakaan yang terjadi tidak serius maka sesegera mungkin diobati. Maka dari itu setiap satu team perusahaan sebelum jalan ke lokasi site di haruskan membawa kotak P3K yang sudah disiapkan oleh manajemen.

Maka dari itu pentingnya diadakannya training serta seminar mengenai K3 pekerja akan mendapat ilmu hal pertama apa yang dilakukan dalam menangani kecelakaan kerja. Dalam penanganan kecelakaan tersebut melibatkan semua pekerja. Setelah terjadinya kecelakaan seorang OHS Officer harus mengisi form kecelakaan kerja untuk dijadikan dokumen.

\section{Melakukan penanganan ketidaksesuaian}

OHS manager akan memperintahkan untuk penghentian pekerjaan apabila ditemukan kondisi berbahaya dan pekerjaan berbahaya tanpa surat izin.

Ketidaksesuaian yang sering terjadi ditemukan saat kerja adalah faktor individu, yaitu sering sekali pekerja mengabaikan keselamatannya dengan tidak menggunakan alat pelindung diri dengan alasan tidak nyaman ataupun mengganggu pekerjaan.

Maka dari itu Coordinator Safety harus lebih ketat dalam pengawasan keselamatan kerja, seperti pemberian sanksi/peringatan tegas kepada pekerja yang tidak mentaati aturan yang berlaku.

\section{Melaksanakan Perbaikan atas ketidaksesuaian}

Coordinator Safety melihat hasil investigasi yang sudah dilakukan. Kemudian menentukan mengapa ketidaksesuaian itu terjadi (identifikasi akar penyebabnya). Menggunakan analisis akar masalah untuk menentukan akar penyebab yang sebenarnya.

Setelah akar penyebabnya sudah kita ketahui maka melakukan tidak lanjut untuk menghilangkan penyebab ketidaksesuaian. Dalam hal ini semua ketidaksesuaian dan tindakan perbaikan harus di dokumentasikan. Perusahaan sudah memiliki form permintaan tindakan perbaikan yang berisi uraian masalah, analisis akar masalah, tindakan perbaikan dan tindakan pencegahan serta analisis efektifitas tindakan yang telah diambil. Ini penting untuk mencegah terulangnya kesalahan yang sama dimasa mendatang.

\section{Melakukan Pemeriksaan atas Perbaikan yang sudah dilakukan}

Setelah perbaikan yang dilakukan oleh Coordinator Safety, maka selanjutnya akan diperiksa oleh $O H S$ Manager. Untuk di cek masalah yang terjadi dan pengambilan keputusan dengan berbagai pertimbangan yang telah dibuat, kemudian dilanjutkan dengan tanda tangan PM.

\section{Membuat Laporan Kerja}

Laporan kerja dibuat untuk mengidentifikasi dan sebagai bahan evaluasi masalah yang terjadi saat kerja. Yang nantinya laporan tersebut diserahkan kepada owner/pemilik proyek. Laporan ini juga menjadi salah satu syarat dalam penarikan termin proyek. Ada beberapa laporan kerja berupa : 
a. Laporan kerja harian

Merupakan laporan kegiatan proyek yang merupakan pertanggung jawaban kontraktor dalam waktu perhari. Nantinya laporan harian ini direkap menjadi laporan mingguan. Dan laporan harian ini harus diberitahukan oleh Engineering Leader kepada OHS Officer dalam bentuk foto dan video yang dikirim melalui salah satu media sosial yaitu whatsaap untuk dijadikan data harian bahwa pekerja sudah melakukan pekerjaannya sampai sejauh mana.

b. Laporan kerja bulanan

Merupakan laporan harian yang direkap dan dijadikan laporan mingguan dan selanjutnya dijadikan laporan bulanan. Laporan bulanan sangat penting sebagai bukti pertanggung jawaban progress kinerja karyawan dan masalah apa yang dihadapi dalam kerja untuk bahan evaluasi nantinya.

c. Laporan kecelakaan kerja

Laporan kecelakaan kerja di buat jika adanya kecelakaan yang terjadi saat kerja. Jika ada nantinya akan dijadikan evaluasi dan dibuat pencegahannya agar tidak terulang lagi kecelakaan tersebut. Laporan kecelakaan kerja dapat dijadikan cerminan perusahaan di mata klien perusahaan. Semakin sedikit angka kecelakaan kerja maka akan baik nama perusahaan tersebut dan dapat dipercaya. Sedangkan bila angka kecelakaannya banyak maka klien akan mempertimbangkannya kembali bahkan menolak untuk bekerja sama, maka dari itu hal ini sangatlah penting bagi perusahaan dalam K3.

\section{Melaksanakan Inspeksi K3/Safety Patroll}

Safety Patroll dilakukan secara tiba-tiba oleh PM langsung yang inspeksi ke lapangan dengan beberapa manajemennya. Inspeksi ini dilakukan oleh PM bertujuan agar pekerja mentaati semua aturan/prosedur yang perusahaan sudah buat demi kebaikan bersama. Agar pekerja sadar betapa pentingnya keamanan dalam bekerja. Jika ada yang terbukti melanggar aturan/prosedur yang sudah dibuat maka perusahaan mengambil tindakan tegas berupa sanksi agar pekerja tidak mengulangi lagi dan selalu mengingat betapa pentingnya keselamatan kerja.

Inspeksi yang dilakukan berupa :

1. Pelaksanaan kerja sudah sesuai dengan prosedur atau belum.

2. Mengontrol masih layak/tidak APD yang dipakai.

3. Memeriksa kelengkapan peralatan kerja.

4. Mengecek semua sarana dan prasarana kerja.

5. Kelengkapan dokumen.

\section{Menyelenggarakan Rapat Koordinasi K3}

Rapat koordinasi K3 dilakukan perusahaan dalam 3 (tiga) bulan sekali yang menyelenggarakan rapat ini adalah Project Manager yang dihadiri oleh Owner, Managing Director, All PM, All Coordinator, OHS Manager dan OHS Officer.

Rapat koordinasi yang dipimpin oleh PM di laksanakan untuk meningkatkan efektifitas dan efisiensi pelaksanaan serta penerapan K3. Didiskusikan pula tentang kelayakan APD, sertifikasi/pelatihan bagi pekerja, dokumen, laporan kerja bulanan, serta laporan kecelakaan kerja dan penyakit akibat kerja yang terjadi yang nantinya akan dijadikan bahan evaluasi bagi perusahaan. Selanjutnya akan dicarikan cara pencegahannya dan solusi terbaik agar kejadian tersebut tidak akan terulang kembali.

\section{Menyusun Laporan Bulanan Safety}

Coordinator safety menyusun laporan bulanan safety dari beberapa team yang telah bekerja.

Hal yang harus diperhatikan dalam penyusunan laporan bulanan safety berupa :

a. Jumlah team yang bekerja dalam satu bulan

b. Jenis pekerjaan yang dilakukan

c. Total pekerja yang menglami kecelakaan/sakit akibat kerja

d. Memeriksa APD yang masih layak dan yang tidak layak

e. Waktu yang dibutuhkan dalam melakukan suatu pekerjaan

f. Kendala apa yang terjadi saat kerja

g. Kelengkapan laporan harian dan mingguan

Herry Syafrial, et.al (Prosedur Keselamatan Dan Kesehatan Kerja (K3) Pada PT. Satunol ...) 


\section{h. Lokasi kerja}

Selanjutnya $O H S$ manager membuat presentasi untuk dijadikan bahan presentasi saat evaluasi.

\section{Mengadakan Evaluasi K3}

Evaluasi K3 dilaksanakan secara internal oleh perusahaan yang dihadiri oleh semua karyawan perusahaan baik yang bekerja dilapangan maupun di kantor. Evaluasi tersebut langsung di pimpin oleh OHS Manager perusahaan.

\section{Menetapkan Tindakan Pencegahan dan Perbaikan}

OHS Manager setelah mengetahui semua laporan yang diserahkan, rapat koordinasi, serta evaluasi yang sudah dijalani maka akan menetapkan tindakan pencegahan dan perbaikan. Agar kedepannya dalam pelaksanaan K3 di perusahaan lebih baik lagi. Serta memberikan rasa kepercayaan kepada klien dan memberikan rasa nyaman kepada para pekerja yang bekerja dengan tingkat resiko yang tinggi.

\section{KESIMPULAN DAN SARAN}

\section{Kesimpulan}

Kesimpulan dari prosedur keselamatan dan kesehatan kerja pada PT Satunol Mikrosistem sebagai berikut:

Ada beberapa tahapan dalam prosedur Keselamatan dan kesehatan kerja pada PT Satunol Mikrosistem antara lain: Sosialisasi mengenai K3; Mengikuti Pelatihan/Sertifikasi K3; Memastikan pekerja sudah tersertifikasi; Melengkapi surat izin kerja; Mengecek form surat izin kerja; Pengecekan kelayakan APD; Pekerja wajib menggunakan APD; Dokumentasi; Melakukan penanganan keadaan darurat; Melakukan penanganan kecelakaan kerja; Membuat laporan kecelakaan kerja; Melakukan penanganan ketidaksesuaian; Melaksanakan perbaikan atas ketidaksesuaian; Melakukan pemeriksaan atas perbaikan; Membuat laporan harian kerja; Melaksanakan inspeksi K3; Menyelenggarakan rapat koordinasi K3; Menyusun laporan bulanan safety; Mengadakan evaluasi K3; Menetapkan tindakan pencegahan dan perbaikan.

\section{Saran}

Berikut beberapa saran yang penulis harapkan bisa dijadikan masukkan untuk meningkatkan efektivitas dan efisiensi kerja pada prosedur keselamatan dan kesehatan kerja pada PT Satunol Mikrosistem :

1. Sebaiknya $O H S$ Officer setelah pekerja sudah selesai menjalani pelatihan/sertifikasi, dokumen berupa sertifikasi dan kartu lisensi harus diamankan terlebih dahulu. Kemudian discan dan disimpan untuk dokumen perusahaan, setelah discan sertifikasi ditahan kemudian kartu lisensinya boleh diberikan kepada pekerja. Bila suatu saat kartu lisensinya tertinggal atau hilang maka perusahaan memiliki cadangannya dalam bentuk softcopy.

2. Diharapkan kedepannya PT Satunol Mikrosistem untuk membuat mading di depan ruang penyimpanan APD, yang nantinya mading tersebut berisi tentang gambar cara pemakaian APD dengan benar, cara perawatan APD dengan baik, dan memberikan gambaran ciri-ciri bila APD sudah tidak layak dipakai. Cara ini menurut penulis lebih efektif untuk pekerja baru yang belum begitu banyak pengetahuan.

3. Untuk mengetahui pekerja yang melanggar prosedur keselamatan kerja seperti tidak memakai APD, penulis menyarankan untuk membuat CCTV secara online di semua site atau lokasi kerja agar bisa diakses dari PT Satunol Mikrosistem dan dibuatkan ruangan khusus. Sehingga OHS Manager dapat mengetahui secara langsung siapa aja yang melanggar standar K3.

4. Bila ada peserta rapat yang tidak bisa hadir dengan berbagai alasan, perusahaan sebaiknya memberikan jalur alternatif berupa membuka conference call.

\section{DAFTAR PUSTAKA}

Budihardjo, M. 2016. Panduan Praktis Menyusun SOP. Raih Asa Sukses. Jakarta.

Buntarto. 2015. Panduan Praktis Keselamatan dan Kesehatan Kerja Untuk Industri. Pustaka Baru Press. Yogyakarta.

Darmiatun, Suryati., dan Tasrial. 2015. Prinsip-Prinsip K3LH. Gunung Samudera. Malang. 
Fajar. 2016. Manajemen Sumber Daya Manusia. Bumi Pustaka. Jakarta.

Hamali, Arif, Yusuf. 2018. Pemahaman Manajemen Sumber Daya Manusia. CAPS Yogyakarta

Irzal. 2016. Dasar-dasar Kesehatan dan Keselamatan Kerja. Kencana. Jakarta.

Laksmi., Ghani, Fuad., dan Budiantoro. 2016. Manajemen Perkantoran Modern. Rajawali Pers. Jakarta

Sedarmayanti. 2017. Manajemen Perkantoran Modern. CV. Mandar Maju. Bandung.

Sholihah, Qomariyatus., dan Fauzia, Rahmi. 2015 Keselamatan dan Kesehatan Kerja (K3) Sekolah. UB Press. Malang.

Sihombing,Sarinah., Gultom, Simon., Sidjabat, Sonya. 2015. Manajemen Sumber Daya Manusia. In Media. Bogor.

Sinambela, Lijan, Poltak. 2018. Manajemen Sumber Daya Manusia. Bumi Aksara. Jakarta.

Soemohadiwidjojo, Arini, T. 2018. Mudah Menyusun SOP. Swadaya Grup. Jakarta.

Sopiah., dan Sangadji, Etta, Mamang. 2018. Manajemen Sumber Daya Manusia Strategik. Andi. Yogyakarta.

Suwardi., dan Daryanto. 2018. Pedoman Praktis K3LH (Keselamatan dan Kesehatan Kerja dan Lingkungan Hidup). Gava Media. Yogyakarta.

Tathagati, Arini. 2017. Step by Step Membuat SOP. Efata Publishing. Sleman.

Umam, Khaerul. 2014. Manajemen Perkantoran. Pustaka Setia. Bandung. 